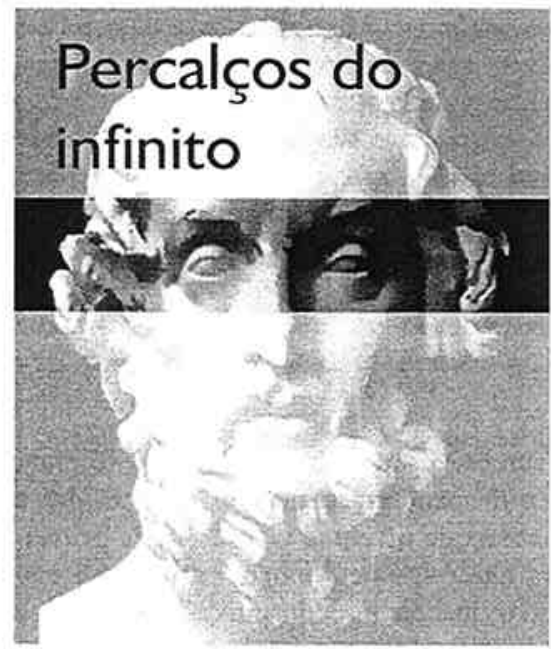

\section{ANTONIO CANDIDO}

Notas de Crítica Literária

Diário de S. Paulo.

10 de janeiro de 1946

Se tentarmos localizar traços comuns nos mais característicos dentre os poetas mais jovens, talvez possamos acentuar um deles, em muitos casos fundamento dos demais. Não sabendo como nomeá-lo exatamente, prefiro dizer que consiste em certo desejo profundo de dar a poesia um aspecto de portentoso mistério. É um quid imponderável, cuja propriedade é comunicar ao mais banal dos gestos, à coisa mais prosaica, um halo de nebulosa grandeza, situando-a além das contingências de tempo e espaço. O leitor que o rotule a seu gosto: multidimensionalismo, anticontingencialismo ou qualquer outra etiqueta rebarbativa.

Pondo desde já as cartas na mesa, deixem-me declarar que pretendo constituir-me em advogado do diabo em relação a esta tendên cia. Não desconheço a sua legitimidade, e sei que, freqüentemente, ela é condiçāo de poesia; o poeta, como todos sabem, é o homem que dá transcendência ao cotidiano e arranca das aparências a centelha do inesperado e do fantástico. Creio, porém, que toda receita bem aviada precisa respeitar escrupulosamente a proporçāo das doses, e na jovem poesia brasileira vislumbro uma infiltraçāo excessiva de transcendência e mistério. Ou, melhor, um abuso das técnicas do mistério, abuso que conduz ao seu desprestígio, numa verdadeira inflaçāo que desmerece cada vez mais o lastro de poesia sem o qual um poema nāo tem valor.

Ordenando as impressōes de leitura, verificaremos a constância de certos processos literários a que a jovem poesia brasileira está dan-

do curso forçado. Notaremos, por exemplo, a ocorrência das mesmas palavras e a exploraçāo das mesmas combinaçōes de palavras com o fim de sugerir os mesmos efeitos, criar a mesma "atmosfera", como diria Greta Garbo. Falemos primeiro das palavras, depois das combi naçōes e, por fim, da atmosfera. Não há quem desconheça o vocabulário relativamente pequeno dos nossos jovens poetas. A sua tendencia é para focalizar, dentro do poema, certas palavras preferenciais, geralmente animais, partes do corpo, instrumentos, plantas etc. Assim, temos no seu estoque: cavalos, com ou sem asas, pombas, havendo acentuada predileção pelos cavalos, cabelos, olhos, braços e seios; telefones e rodas; árvores e folhas; nuvens, nāo contando os anjos, que nāo sei bem se devo pôr entre os instrumentos, os bichos, as partes do corpo. Há também, a bem-amada, sempre em evidência, quer sob um nome romântico, quer sem maior especificaçāo.

Estes vocábulos, ou melhor, os vocábulos que designam estes seres e objetos, formam o estoque da jovem poesia. Cada geração tem o seu, e nós ainda hoje vibramos com o sabiá, o céu azul, o salgueiro, o Infinito e o Poeta, de estoque romântico.

De posse deste material básico, o jovem poeta passa à etapa seguinte, da conotaçāo. A linguagem da poesia, como sabemos, é mais conotativa que denotativa, para usar o jargão dos especialistas. A de notaçāo consiste em atribuir a um vocábulo o seu significado lógico e fazê-lo seguir de outros, logicamente complementares. Exemplo: "A patativa, senhores, é o mavioso cantor de meu torrão" (Rui Barbosa). Contrariamente, a conotação consiste em associar a um vocábulo dado outros vocábulos que a ele se prendem por uma necessidade não lógica, mas poética. Exemplo: "O vento em ré maior / Prepara o temporal / Desfolha as estátuas, / Parte as hélices dos anjos" (Murilo Mendes). $O$ vento não obedece ao pentagrama, estátua não tem folha, nem anjo hélice, é claro. No entanto, um jogo de analogias, associaçōes e reminiscências permite ao poeta transformá-los à sua vontade, substituindo a análise lógica pela síntese poética. Observe-se que há poemas, mas não poesia puramente conotativa; da mesma forma, há poemas, mas nāo poesia puramente denotativa.

Assim, o trabalho do poeta consiste, sob certo aspecto e em certa fase, na escolha do material trazido pela inspiração, estabelecendo as conotaçōes que melhor convêm ao efeito procurado. Na poesia moderna, como na poesia barroca, é frequente a conotaçāo estranha e aparentemente forçada. Mefistófeles ensinava ao Estudante que é preciso começar por apertar o espírito nas botas da lógica. Em poesia, é preciso freqüentemente apertar a imaginaçāo no tornilho duma comparação inesperada ou de associaçōes aparentemente sem sentido - como vimos na belíssima estrofe de Murilo Mendes, citada há pouco. Os nossos jovens poetas (eis o meu libelo) nem sempre utilizam com a devida parcimônia e indispensável segurança as técnicas da conotação. 
A associaçāo poética se subordina a certa "necessidade", a uma pertinência estética ou psicológica na conjunçāo das palavras ou imagens, reminiscência vivida e amadurecida, iluminação, descoberta paciente. O poeta perde o tônus e compromete a qualidade da sua poesia ao associar friamente ou apenas com habilidade. Em muitos poemas de muitos dos nossos jovens poetas, julgo discernir certa tendência para empregar como simples truque as técnicas da associação poética. Perceberam cedo, lendo os maiores, que, por exemplo, um anjo olhando no binóculo o som de um telefone de que nascem flores qualquer coisa de bizarro, no sentido correto e no sentido galicista. Que, portanto, o leitor se sentirá provavelmente envolvido por um sentimento de mistério e de fantasmagoria, atrás do qual ele, poeta, oculta a sua preguiça mental e a sua incapacidade de pesquisa. Quantas vezes, vendo o hieratismo com que as amadas mortas mandam mensagens enquanto a trombeta do arcanjo celebra o fim do mundo, quantas vezes nos sentimos com vontade de rir ante o malabarismo pueril desses pastiches sern vida!

Precisando o que ficou dito, resumo numa frase esta censura à maioria dos nossos jovens poetas, em muitos dos quais reconheço não obstante as melhores qualidades: falta de esforço para renovar o vocabulário herdado e abuso quase mecânico de uma conotaçāo superficial e pouco pensada.

Mas (e aqui chegamos ao ponto principal), com que intuito buscam eles as convençōes da conotação moderna? Com o intuito, já as sinalado, de criar uma "atmosfera", de alargar infinitamente o eco e o significado dos versos. A atual poesia brasileira padece, sob certos aspectos, duma espécie de gigantismo. Os poetas nāo mais se conformam em ver um sabiá, como Gonçalves Dias; em cada pássaro, farejam, no mínimo, a Pomba, o Mensageiro, o espírito divino da poesia. Sua namorada, telepaticamente, fá-los comunicar com o infinito, e os gestos simples adquirem a solenidade imensurável das coisas eternas. Todo o esforço visa barrar passagem ao cotidiano - o Vil!

Creio não haver no que digo exagero ou maldade. É fato de observaçāo corrente essa acromegalia literária, que transforma a vida do espírito numa tensão excepcional, contínua, e a percepção do mundo num êxtase inefável. Ora, as qualidades das coisas e das idéias se definem em relaçāo a outras tantas qualidades. Num mundo em que toda violeta é nada menos que a consubstanciaçāo das essências, qual o valor poético das essências? Para ser vidente, ambição louvável e digna, o poeta precisa, no minimo, de uma etapa anterior que sirva de contraste e lhe permita reconhecer a si mesmo como vidente. Pareceme claro que a acromegalia literária, a inflação do infinito, suprime os pontos de reparo e torna inoperante a atitude transcendente. No reino dos anjos (sempre pensei) a vantagem é nāo ter asas e não sabe tocar trombeta. Por isso, a minha terceira e última censura aos jovens poetas brasileiros é a de estarem maltratando o mundo sensivel e se encaminhando para uma desagradável grandiloqüência, que transforma em regra banal e desapaixonada as exceçōes sublimes do mistério e do inefável.

De um ponto de vista histórico-literário, o fenômeno indicado parece uma espécie de reaçāo ao pragmatismo de que se revestiram alguns aspectos do nosso "modernismo" literário. Os modernistas procuraram revigorar e revalorizar o estoque de imagens poéticas, apegando-se por isso, entre outras coisas, ao registro do mundo exterior, a fim de dar ingresso em poesia a uma série de objetos proscritos ou não recolhidos.

A vista renasce na manhā bonita.

Paulicéía lá em baixo epiderme ásper

Ambarizada pelo Sol vigoroso,

Com o sangue do trabalho correndo nas veias das ruas.

- Torres. Cheiros.

- Barulhos .

-E fábricas...

Estes versos de Mário de Andrade são típicos de uma geraçāo que procurava reconciliar-se com o mundo concreto, reorganizando a sensibilidade por meio de um novo sistema de imagens, diretamente anotadas.

\section{Surpresa do encontro \\ Com o fantasma \\ Na praia: Camisa branca, \\ Cotpo diäáano, \\ Funçōes tranqüilas \\ No banho de sol}

Estes versos de João Cabral de Melo Neto são típicos da atual geraçāo, que procura evadir-se do mundo concreto, infundindo nas imagens da vida uma doze máxima de abstração, a ponto de transformar o cotidiano em chafariz permanente de milagres.

Qual foi o destino dos "modernistas"? Começaram por ficar em paz com o mundo; abriram os sentidos e receberam as impressōes, concretizando-as em imagens diretas e quase materiais, reeducando a sensibilidade no primitivismo das sensaçōes. Muitos lá ficaram, e a sua poesia nos parece hoje tão velha e sem sentido quanto a dos últimos parnasianos. Outros partiram dali, nutridos de experimentaçāo com as coisas, para uma lenta reconquista das harmonias permanentes da poesia. Afinaram, volatilizaram ou transportaram o seu verso depois de lhe haver dado músculos algo selvagens. Daí o segredo dos grandes livros da nossa poesia moderna: Estrela da manhā, Sentimento do mundo, Livro azul, Poesia em pânico. Os jovens, porém, se projetam. diretamente no espaço procurando, de início, captar a harmonia das esferas. Fazem ressoar majestosamente uma corda que vai do seu 
umbigo ao "infinito", reentronizando a velha noção romântica do poeta-cósmico, do poeta-centro-do mundo.

\section{Nāo, oh mortais, não vos pertenço, (exclama)}

Eu sou órgāo de um Deus:

Seu intérprete sou; oh terra! Ouvi-me.

Esses versos modernos de Gonçalves de Magalhães estão na ordem do dia. Penso que nāo há grande mal no poeta julgar-se predestinado, mas creio também, no entanto, que a terra só o ouve depois que ele ouviu a Terra. Depois que aprendeu a identificar o sabiá sobre a palmeira e transpô-los para a poesia "enquanto" sabiá e palmeira, confiando no magnetismo da sua sugestão. Se, em vez disso, monta o pássaro de Gonçalves Dias num telefone de Manuel Bandeira e afirma que o resultado é igual à transmigração das almas (digamos), corre o risco de nunca aprender a manejar e respeitar o que há de máximo na arte poética, isto é, as imagens, nutridas de mensagens da terra.

Do ponto de vista humano, há perigos enormes nesse exclusivismo em cultivar apenas as "emoções que se agrupam em torno da palavra infinito", como dizia Hulme. É a invasāo do desmesurado, que parecendo exaltar o humano, nada mais faz que hipertrofiá-lo, isto é, desumanizá-lo. Com efeito, em muitos livros recentes, encontramos pouca fibra, pouca atitude realmente viril ante a criaçāo. Não censuro propriamente os nossos jovens poetas, que estão jogando uma grande cartada renovadora, e que tomados isoladamente tèm, muitas vezes, qualidades suficientes. Procurei apenas conceituar certas generalidades que podem apresentar perigo, mas que, nem por se aplicarem em conjunto, bastam para explicá-los.

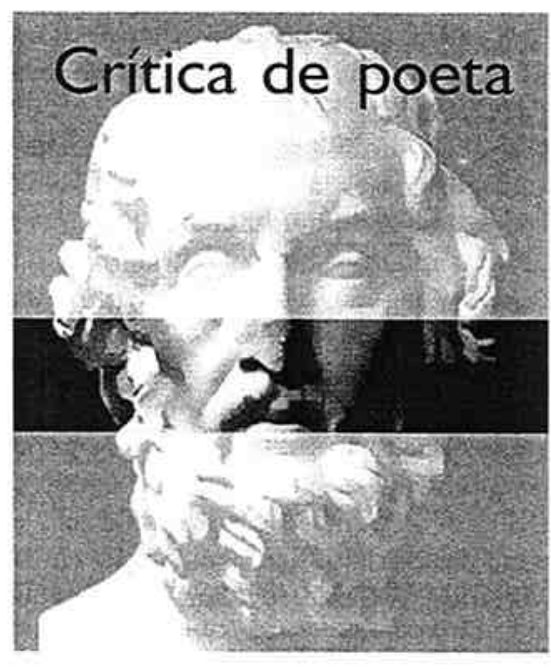

ANTONIO CANDIDO

Notas de Crítica Literária

Diário de S. Paulo, 7 de março de 1946.

Conversando nāo faz muito com um dos nossos maiores poetas, dizialhe eu entre outras coisas que a melhor crítica literária, a mais iluminadora e durável, não é feita pelos críticos profissionais, mas pelos próprios artistas criadores. Concordamos, é verdade, que o crítico ocasional tem a seu favor a vantagem enorme de escrever quando quiser, sobre os livros que escolher, donde a preeminência, mais aparente que real segundo o meu delicado interlocutor. Dum jeito ou de outro não vejo razōes para mudar de parecer, embora me punja a idéia desta precariedade da minha corporação, tāo contingente e frágil que no seu próprio terreiro vem batê-la a mestria dos criadores.

Se, encarada no conjunto, a obra de Tristão de Ataíde, de José Veríssimo e a ainda efervescente de Alvaro Lins apresentam maior força e importância na história do gênero, não há negar que as páginas mais penetrantes, os conceitos mais brilhantes, as idéias mais reveladoras sobre a nossa literatura sāo encontrados sob a pena de Machado de Assis, Mário de Andrade, Carlos Drummond, Manuel Bandeira. Se Mario de Andrade é um crítico perfeitamente caracterizado, como outros de igual valor que fazem no gênero estaçōes periódicas (Pedro Dantas, Sergio Buarque de Hollanda, Barreto Filho), os demais apenas circunstancialmente analisam um livro. $E$ ao fazê-lo (aqui chego a meu alvo) demonstram geralmente acuidade maior que a dos críticos profissionais. Assim é que uma simples frase desse indisciplinado e por vezes caótico Oswald de Andrade sobre "literatu- 